\title{
Identification and Natural Control of Mite in Ras Cheese
}

\section{Dawood SAA ${ }^{1 *}$ and Ali FS ${ }^{2}$}

${ }^{1}$ Dairy Science Department, Faculty of Agriculture, Cairo University, Giza, Egypt

${ }^{2}$ Department of Zoology and Nematology, Faculty of Agriculture, Cairo University, Egypt

\begin{abstract}
Ras cheese samples were found to be predominantly infested with A. siro mite. Clove, thyme, rosemary and citrus essential oils showed effective acaricidal activity against Ras cheese mites (A. siro). essential oil. However, treatments of clove or rosemary essential oil negatively affected the cheese flavor. However, degree of acaricidal activity varied according to the type and concentration of the essential oil. Clove essential oil was found to be the most effective oil against cheese mite. Ras cheese flavor was improved by citrus or thyme Essential oil type affected the general acceptability of the cheese. Ripened cheese treated with citrus or thyme essential oil showed more general acceptability than other treated cheeses.
\end{abstract}

Keywords: Ras cheese; Mite identification; Mite control; Essential oils

\section{Practical Applications}

Ras cheese is infested with mite especially A. siro. Infestation with mite lowers the quality of the cheese and causes economic loss. Chemicals used in controlling mite may pose risks to human health. Natural substances with acaricidal activity could be an alternative of chemicals for mite control. This research suggested using clove, thyme, rosemary and citrus essential oils for controlling mites in Ras cheese. In addition, using essential oils can reduce microbial contamination and increase shelf life of Ras cheese.

\section{Introduction}

Mites are among the troublesome pests of a wide variety of stored foods. It is particularly common in foods with high level of fat and protein, such as nuts, ham, dried eggs and cheese [1]. Hard and semi hard cheese are Known to be prone to attack of mites. Mites are more attracted and colonized in Ras cheese as the ripening and decomposition progresses [2,3]. Cheese mites normally live on the external surface of cheese, but sometimes penetrate inside. Severe infestation during curing and storage is usually accompanied by a considerable development of microorganisms especially fungi, which results in extensive damage and serious economic loss [4]. Mites may also consume a large amount of cheese, leaving their debris, dead bodies and excreta on the cheese as powdery dust disliked by the consumers and unfit for human consumption. The presence of a large number of these pests in stored cheese can cause gastrointestinal disorders in human ingestion [5]. Cheese mites as other storage mites are also frequently reported as being the cause of several allergic diseases [6]. Allergic rhinitis, asthma and various types of dermatitis are frequently reported worldwide among cheese workers and children [7]. Increased production and storage of large surpluses of Ras cheese have accentuated the need for protection from mite infestations. Chemical and physical methods for protecting cheese against mites have been long applied [8]. However, these methods may adversely affect physical and rheological properties of cheese and retard cheese ripening $[9,10]$. In addition, chemicals may pose risks to human health [11]. On the other hand, there has been an increasing interest in use of natural substances for protecting food from pests [12]. The acaricidal effects of plant essential oils as natural substances have been extensively reviewed. In various studies more than 150 different essential oils have been tested for acaricidal effects under laboratory and field conditions [13]. Several reports suggested the use of essential oils for controlling mites [14]. On the other hand, essential oils have gained great popularity as consumers have developed a particular ever-growing awareness toward the use of natural ingredients in food products [15-17]. In the current research, mites infested Ras cheese were identified. Potential acaricidal activity of four essential oils for protecting Ras cheese against mites was investigated. Effects of essential oils on microbiological and organoleptic properties of Ras cheese were also determined.

\section{Materials and Methods}

\section{Mites isolation and identification}

Mites were isolated at the Acarology Lab, Cairo University. Twenty five Ras cheese samples, of $250 \mathrm{~g}$ each were collected in plastic bags from different grocery stores in Giza, Egypt and its suburbs. Cheese samples were kept in an incubator at $16 \pm 2{ }^{\circ} \mathrm{C}$ and $80 \%$ relative humidity. Mites were extracted from cheese samples by modified Tullgren funnels with $2 \mathrm{~cm}$ deep muslin layers [18]. The isolated mites were cleared in Nesbitt's solution, and then mounted in Hoyer's medium on glass slides. Slides were microscopically examined by Leica Microsystems compound microscope (Nikon polarizing microscope EClIpsEv100POL). The features of identifying mite species included idiosoma length, shape of body and legs (Figures 1-4), idiosomal setae (Figures 1, 2 and 5), solenidia shape (Figure 2), anus and genital placement (Figures 1 and 6), setae arrangement around the genitals and anus (Figures 1, 5 and 6) and chaetotaxy of the ventral side (Figures 2,4) [19]. Distinct characteristics were used to identify Acarus siro. On the back of $A$. siro's body there is an incision between the 2nd and 3rd pair of legs. The males of $A$. siro possess tarsal and anal suckers as well as a clearly expressed hook-like extension at the thighs of the first leg pair. The females possess a claw at the end of each foot. Both sexes possess 4 long dragging hairs on the back end [20]. For producing population of $A$. siro, isolated mites were transferred to rearing chambers. Dry Baker's yeast granules were added as food and drops of

*Corresonding author: Dawood SAA, Dairy Science Department, Faculty of Agriculture, Cairo University, Giza, Egypt, E-mail: saboudawood@hotmail.com

Received December 25, 2014; Accepted March 10, 2015; Published March 17 2015

Citation: Dawood SAA, Ali FS (2015) Identification and Natural Control of Mite in Ras Cheese. J Food Process Technol 6: 435. doi:10.4172/2157-7110.1000435

Copyright: (c) 2015 Dawood SAA, et al. This is an open-access article distributed under the terms of the Creative Commons Attribution License, which permits unrestricted use, distribution, and reproduction in any medium, provided the original author and source are credited. 


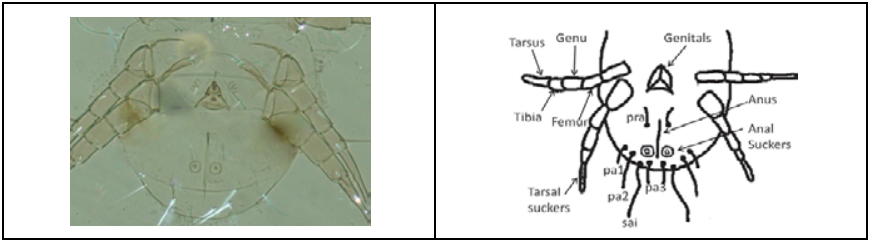

Figure 1: Ventral view of identified $A$. siro male (Left). Position of leg segments, genitals, anus, anal suckers, tarsal suckers, and setae of the anus: 3 postanals (pa1, pa2, and pa3) and preanals (pra). sai $=$ internal sacral setae of $A$. siro (from Hughes [1]) (Right).

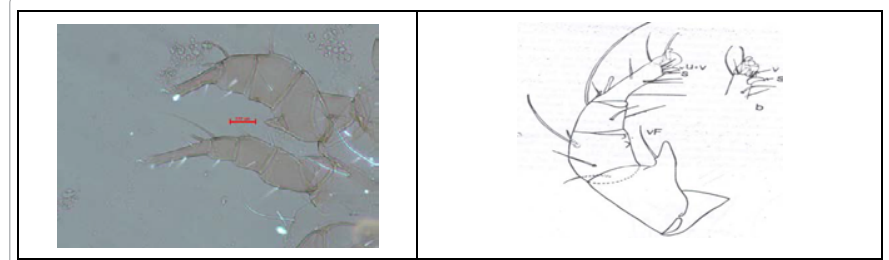

Figure 2: Femur of 1st leg of A. siro male (left). A. siro's first Leg has an enlarged genu and a femur and a spur projecting from the ventral side of the femur from which arises the seta (VF). Two blunter thickening of the cuticle are also present on the ventral side of the genu (from Hughes [1]) (Right).

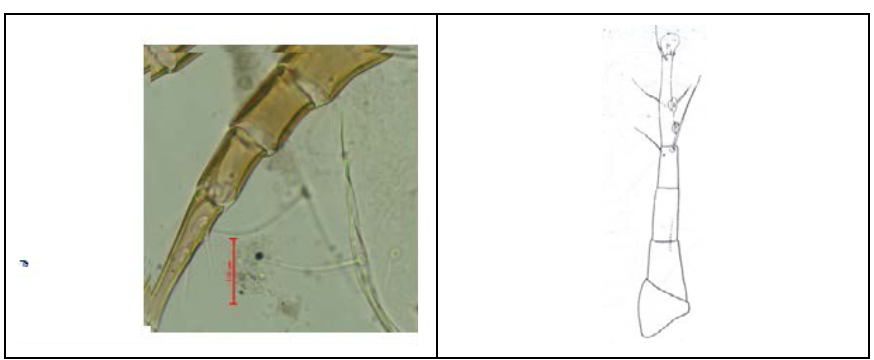

Figure 3: Tarsus of 4 th leg of $A$. siro male (Left). A tarsus of 4 th leg of male and suckers on 4th tarsus of the male are separate from one another by distance equal to their diameter, and are nearer to the base than to the apex of the segment (from Hughes [1]) (Right).

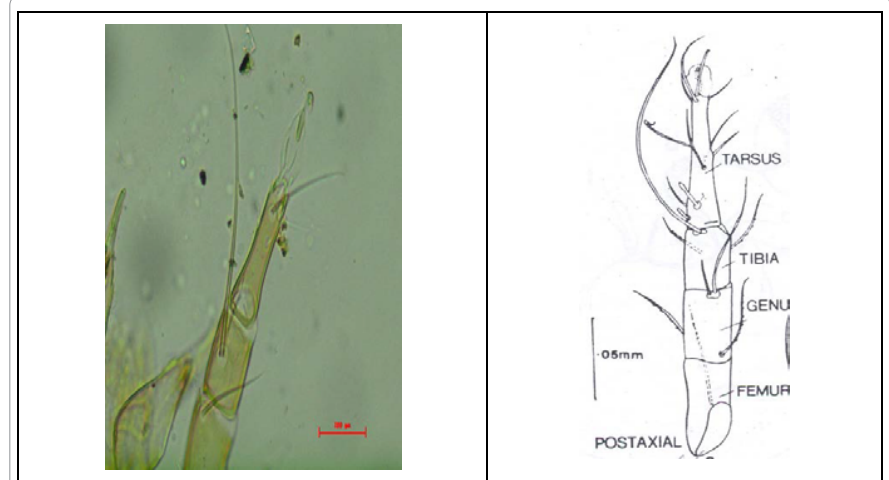

Figure 4: Tarsus of $1 \mathrm{st}$ leg of $A$. siro female (Left). Tarsus of 1 st leg of female Ventral distal spine of tarsi 1 is large, about equal to length of tarsal claw. Ventro-posterior margin concave tip directed back words (from Hughes [1]) (Right).

water as a source of humidity. Cultures were kept at $20 \pm 2^{\circ} \mathrm{C}$ and $60 \pm$ $5 \%$ relative humidity. For solitary rearing, newly deposited eggs of well identified females were transferred to plastic blocks of $3 \times 3 \times 0.5 \mathrm{~cm}$ (an egg per a block). Each block contained a small rearing circular chamber of $1.2 \times 0.4 \mathrm{~cm}$. The bottom of each chamber was filled with mixture of Plaster of Paris and charcoal. The plastic block was covered with a rubber band and kept in incubator at $20 \pm 2^{\circ} \mathrm{C}$ and $60 \pm 5 \%$ relative humidity. After hatching, Baker's yeast and drops of water were daily added. Larvas were kept till reaching adulthood to be used in acaricidal essay of the essential oils.

\section{Cheese manufacture}

Fresh cow and Buffalo milk was obtained from Dairy Pilot Plant at Cairo University. Raw mixture of cow and buffalo milk at 1:1 of $4.5 \%$ fat and $0.17 \%$ titratable acidity was pasteurized at $72^{\circ} \mathrm{C}$ for $15 \mathrm{~s}$. Starter culture of Lactococcus lactis subsp lactis in a form of freeze dried-direct vat set (FD-DVS) was obtained from Danisco (France). Starter culture was added at $2 \%$. Calcium chloride $\left(\mathrm{CaCl}_{2}\right)$ was added at $0.01 \%$ to milk at $32^{\circ} \mathrm{C}$. The inoculated milk was held for $60 \mathrm{~min}$ at $32^{\circ} \mathrm{C}$, and then calf rennet was added at $2 \%$. The coagulum was cut both vertically and horizontally into $2 \mathrm{~cm}$ cubes with a large, two-handled knife. The curd was allowed to rest in the whey for $5-10 \mathrm{~min}$. The curd was heated to $45^{\circ} \mathrm{C}$ over $30 \mathrm{~min}$ and held at this temperature for $30 \mathrm{~min}$ more. The whey was drained when $\mathrm{pH}$ reached 6.0. The curd was salted at $(2.0 \%)$, hooped in blocks, pressed two days at $2.5 \mathrm{~kg} / \mathrm{cm}^{2}$. The produced fresh cheese cylinders (Figure 7) were placed on stainless steel sieves with regular flipping under controlled conditions of $16 \pm 2^{\circ} \mathrm{C}$ temperature and $80 \%$ relative humidity for 30,60 and 90 days.

\section{A caricidal essay of the essential oils}

Clove (Syzgium aromaticum), thyme (Thymus vulgaris), rosemary (Rosmarinus officinalis) and citrus (Citrus limon) essential oils were purchased from Kato Aromatic, SAE (Haraneya, Giza, Egypt). Corn oil produced by Lesieur (Asnieres-sur-Seine, Cedex, France) was used to dilute the essential oils. Ras cheese cylinders were sliced to $4 \times 4 \mathrm{~cm}$ in surface area and $4 \mathrm{~mm}$ in thickness slices. Cheese slices were placed in separate $10 \mathrm{~cm}$ Petri dishes (Figure 8). Upper surface of three slices were wiped with clove, thyme, rosemary or citrus essential oils at $0.1,0.2,0.4$, $0.6,0.8,1.0$ and $4.0 \%$. Three slices were left without oil treatment to be used as control 1 . Other three slices were wiped with corn oil to be used as control 2. All petri dishes were left overnight. Twenty A. siro mites of 7-10 days old were placed on each cheese slice. The Petri dishes were carefully closed, kept in dark at $16 \pm 2{ }^{\circ} \mathrm{C}$. Mortality of mites was determined after 24 hours under a stereomicroscope. Mortality was determined as percentage of dead mites. Mites which cannot move their appendages when stimulated with a fine pin were considered dead. The same procedure was followed using Ras cheese stored for 30, 60 , and 90 days. Thyme, rosemary, citrus and clove essential oils were treated at $1.0,1.0,0.8$ and $0.1 \%$, respectively.

\section{Microbial examination}

Outer layer of the cheese cylinders with 1-2 cm deep was separated for microbiological analysis. Sample of $10 \mathrm{~g}$ of fresh and stored for 30 , 60 and 90 days were homogenized with vortex in $90 \mathrm{ml}$ of warm $\left(40^{\circ} \mathrm{C}\right)$ $2 \%$ sterile sodium citrate solution for $3 \mathrm{~min}$. Subsequent serial dilutions were made in Ringer's solution. One $\mathrm{ml}$ of each dilution was plated onto a separate $10 \mathrm{~cm}$ Petri dish. Then, $20 \mathrm{ml}$ of the specific media was smoothly added. Five Petri dishes were used for each medium. Nutrient agar, violet red bile agar, potato dextrose agar were used for counting total, coliform bacteria, and moulds and yeast, respectively. Protiolytic bacteria were counted and incubated at $25^{\circ} \mathrm{C}$ for 3 days. Protiolytic bacteria were counted according to Frank et al. [21] using plate count agar plus $10 \%$ sterile skim milk. Lipolytic bacteria were enumerated according to the method described by Diliello [22] using nutrient agar medium with olive oil. After agar solidification, Petri dishes were 


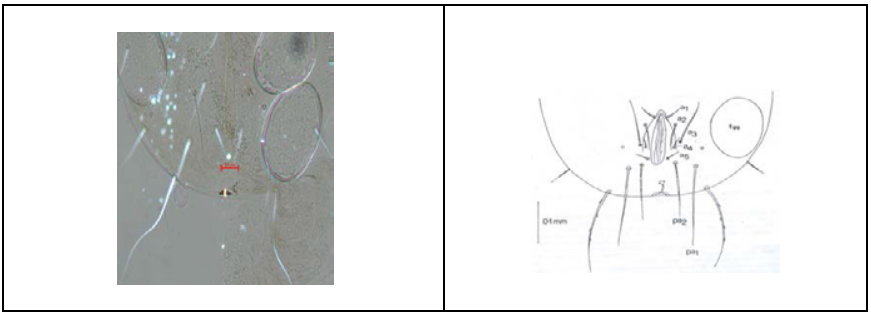

Figure 5: Anal region of $A$. siro female (Left). Anal region has five pairs of setae (from Hughes [1]) (Right).

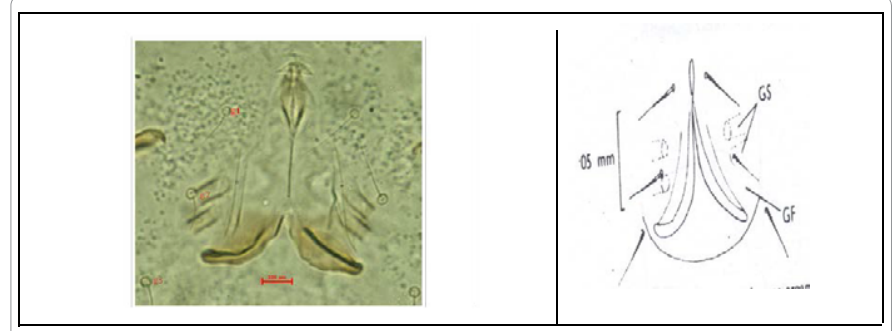

Figure 6: Genital of $A$. siro female (Left). Bases of genital setae and flanking pair of coxal suckers, almost in line. Distance between base of sucker and base of seta is less than width of setal base (from Hughes [1]) (Right).

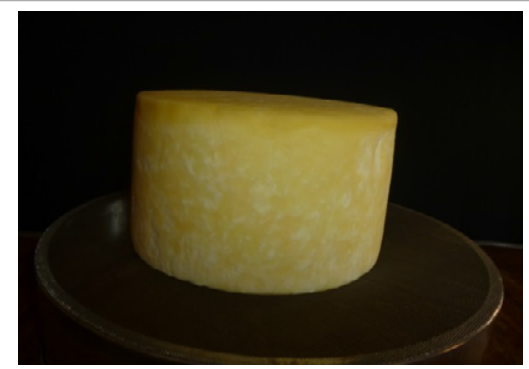

Figure 7: A Ras cheese cylinder was placed on stainless steel sieve for ripening.

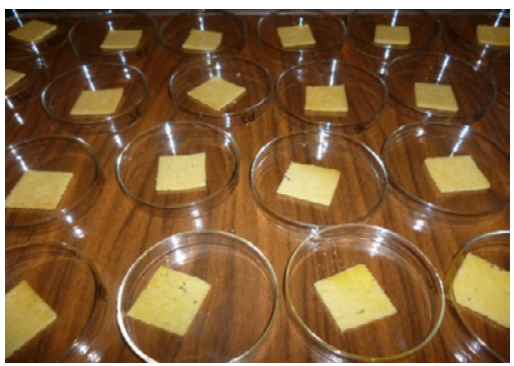

Figure 8: Ras cheese slices with surface area of $4 \times 4 \mathrm{~cm}$ and thickness of 4 $\mathrm{mm}$ treated with clove, thyme, rosemary or citrus essential oils were used for assaying the acaricidal activity.

aerobically incubated upside-down at $32^{\circ} \mathrm{C}$ for 72 hours, $30^{\circ} \mathrm{C}$ for 24 hours, $32^{\circ} \mathrm{C}$ for 2 days and $25^{\circ} \mathrm{C}$ for $4-5$ days for total, coliform, lypolitic and protiolytic bacteria, and mould and yeast, respectively. Only plates with 30-300 colonies were counted. All colonies were counted for total bacteria. The small non mucoid red colonies were counted for coliform bacteria. White, cream or yellow colour with fuzzy edges colonies were counted for mould and yeast. Proteolytic bacteria colonies were identified by the presence of clear zones around the colonies, after adding $\mathrm{HCl}$ at $1 \%(\mathrm{v} / \mathrm{v})$ for $1 \mathrm{~min}$. The lipolytic colonies were identified by copper sulphate at $20 \%$.

\section{Sensory evaluation}

Surface of sets of four fresh (green) Ras chees cylinders were wiped with each of thyme, rosemary, citrus and clove essential oils at 1.0, 1.0, 0.8 and $0.1 \%$, respectively. A set of four cheese cylinders were left without oil treatment to be used as control 1. Other four cheese cylinders were wiped with corn oil to be used as control 2 . The cheese cylinders were kept in a dark place, allowed to ripe under controlled conditions of 16 $\pm 2^{\circ} \mathrm{C}$ temperature and $80 \%$ relative humidity. Samples of fresh and after 30, 60 and 90 days of storage were taken for sensory evaluation. A panel of 25 assessors of faculty and staff members of Dairy Department, Faculty of Agriculture, Cairo University, participated in the Descriptive Sensory Analysis (DSA). These assessors are experienced with sensory tests of dairy products. The panel of assessors evaluated the products for flavor, texture, color and odor. The quantity of each descriptive attribute perceived was scored on a 10 points scale. In addition, panel members were also instructed to report any comments. Cheese samples of $20 \mathrm{~g}$ were used in evaluation.

\section{Statistical analysis}

Data were analysed by one-way ANOVA. LSD multiple comparisons were used to test the differences between treatments at $P<0.05$.

\section{Results and Discussion}

Microscopic examination showed that the collected Ras cheese samples were mainly infested with $A$. siro and A. Farris of acaridae and Carpoglyphus lactis of carpoglyphidae. A. siro was found to be the predominant mite species in the cheese samples and constituted $82 \%$ of the isolated mites (Figures 1-6). A. Siro's predominant food source is flour, hay, dried fruit and cheese. Elziny [3] found that A. Siro among other species was found in Ras cheese. Melnyk et al. [23] found A. Siro to be the predominant mite in two other cheese types. Some authors reported that fungi growing in the feed are also consumed by these mites [24]. Clove, citrus, thyme and rosemary essential oils showed effective acaricidal activity against Ras cheese mites (A. siro). However, degree of acaricidal activity varied according to the type and concentration of the essential oil (Figures 9, 9A-D). Clove oil found to be the most effective oil against cheese mites. $\mathrm{LD}_{50}$ (the oral dose at which 50 percent of the mites were killed) of clove oil was $0.1 \%$ with 95 percent of mites mortality. Percentage of mortality reached 100 with the higher clove concentrations. Clove oil is known to possess potent acaricidal activity against mites [25]. The primary component of clove oil is eugenol [26]. $\mathrm{LD}_{50}$ of both thyme and rosemary oils was $1.0 \%$ with mortality of 75 and 55\%, respectively. Higher concentrations of both oils improved mites control in the cheese. Rosemary and thyme are reported to have acaricidal activity $[27,28]$. Both essential oils were used for pest control in organic farming [29]. Citrus essential oil reached the

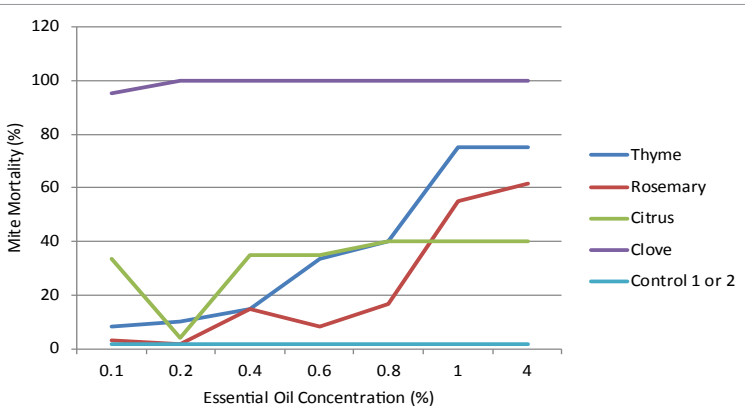

Figure 9: Effect of essential oils on mortality (\%) of $A$. siro on Ras cheese 


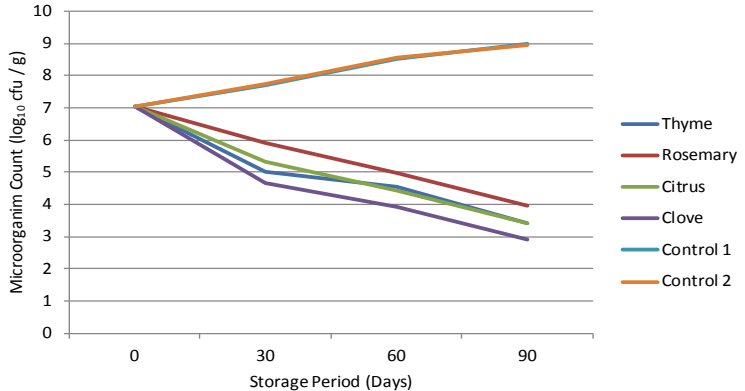

Figure 9a: Effect of essential oils on Total bacteria (\%) of $A$. siro on Ras cheese.

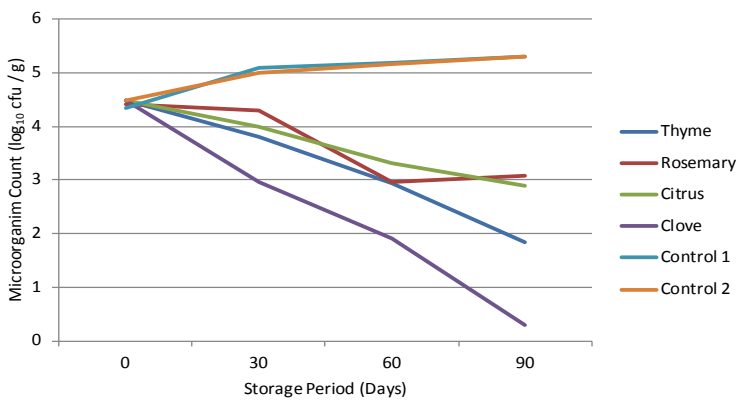

Figure 9b: Effect of essential oils on Proteolytic bacteria (\%) of $A$. siro on Ras cheese.

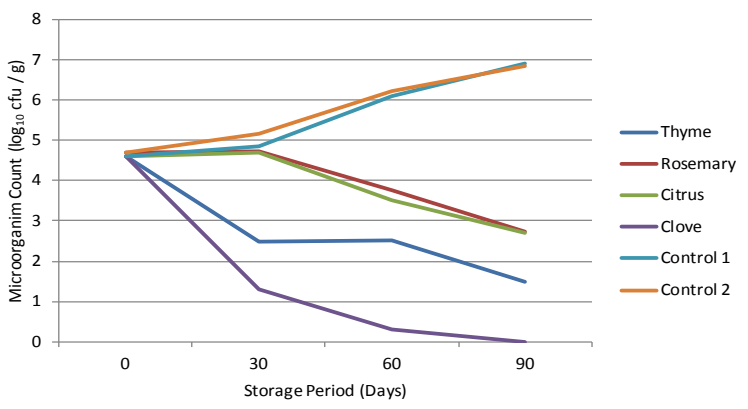

Figure 9c: Effect of essential oils on Lypolytic bacteria (\%) of $A$ siro on Ras cheese.

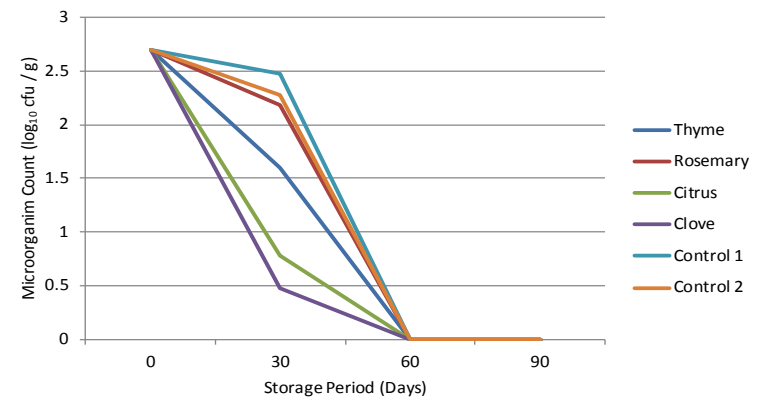

Figure 9d: Effect of essential oils on Coliform bacteria (\%) of $A$. siro on Ras cheese.

best acaricidal activity at $0.8 \%$. Control samples treated with corn oil or without any treatment showed dramatic infestation with mites. Clove, citrus, thyme and rosemary essential oils showed acaricidal activity against Ras cheese mites during ripening period (Table 1). Percentage of mortality on fresh and 30 days old Ras cheese treated with thyme essential oil was 76 and $75.6 \%$, respectively. After 90 days of storage, percentage of mortality on the cheese with the same treatment was $74 \%$. Mortality on fresh cheese treated with rosemary essential oil was $59.8 \%$ and decreased to $53.6 \%$ at the end of storage period. Cheese treated with citrus essential oil showed the least acaricidal effect after cheese storage for 90 days with $39.5 \%$ mortality. Clove essential oil was the most effective against mite during the storage period with $94.5 \%$ mortality after 90 days of storage. Besides their acaricidal effect, the tested essential oils showed anti-microbial activities in Ras cheese (Figure 10). Moulds on Ras cheese were mentioned to be necessary for sustaining growth and activity of mites. On other hand, microbial communities play an important role in cheese ripening and determine the flavor and taste of the cheese [30]. Fresh cheese samples showed no significant differences in the total, coliform, proteolytic and lypolytic bacteria or mould and yeast count among essential oils treatments. Total, coliform, proteolytic and lypolytic bacteria and mould and yeast counts were decreased during storage period in all treatments. Clove essential oil treatment was the most effective in decreasing microbial counts, followed by thyme, citrus and rosemary essential oils, respectively. Clove treatment eliminated coliform bacteria and mould and yeast after 60 days of storage. Clove essential oil was reported to possess significant antimicrobial effects against many microorganisms [31,32]. Rosemary essential oil was reported to possess significant antimicrobial effects against several microorganisms [31]. Thyme essential oil was considered as a source of a natural antimicrobial for food industry [33]. Also, citrus essential oil can provide the natural antimicrobials that the food industry requires to fulfil both its requirements and those of the consumer [34]. Generally, essential oils have been long recognized for their antibacterial and antifungal properties [35-38]. Essential oils were widely used in medicine and food industry for anti-microbial properties [39]. Citrus and thyme treatments improved the odour of Ras cheese (Table 2). However, clove and rosemary adversely affected the cheese odour. Odour is the primary feature of essential oils when utilized as part of food products. Citral is the key aroma component of citrus odour and flavour [40]. The main source of odour in thyme is thymol and carvacrol [41]. On the other

\begin{tabular}{|c|c|c|c|c|}
\hline \multirow{2}{*}{ Essential Oil } & \multicolumn{4}{|c|}{ Storage Period (Days) } \\
\cline { 2 - 5 } & 0 & 30 & 60 & 90 \\
\hline Thyme & 76.6 & 75.6 & 75.5 & 74 \\
\hline Rosemary & 59.8 & 54.5 & 53.8 & 53.6 \\
\hline Citrus & 46.5 & 42 & 39.8 & 39.5 \\
\hline Clove & 97.6 & 97.5 & 96 & 94.5 \\
\hline Control 1 & 2.5 & 2.1 & 1.8 & 1.6 \\
\hline Control 2 & 2.3 & 2.1 & 1.8 & 1.7 \\
\hline
\end{tabular}

Table 1: Effect of essential oils on mortality (\%) of $A$. siro on Ras cheese during ripening.

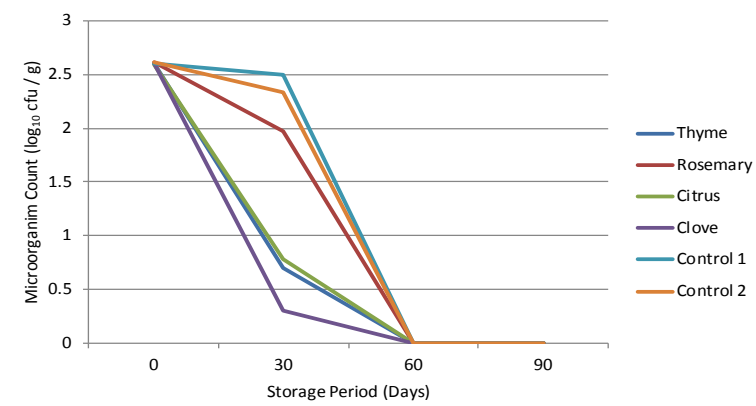

Figure 10: (Mould and yeast E) Microbiological analysis of Ras cheese treated with essential oils $\left(\log _{10} \mathrm{cfu} / \mathrm{g}\right)$. 
Citation: Dawood SAA, Ali FS (2015) Identification and Natural Control of Mite in Ras Cheese. J Food Process Technol 6: 435. doi: 10.4172/2157-7110.1000435

Page 5 of 6

\begin{tabular}{|c|c|c|c|c|c|c|}
\hline \multirow{2}{*}{$\begin{array}{l}\text { Storage Period } \\
\text { (Days) }\end{array}$} & \multirow[t]{2}{*}{ Treatments } & \multicolumn{5}{|c|}{$\begin{array}{l}\text { Organoleptic Properties } \\
\text { (10 points scale) }\end{array}$} \\
\hline & & Odor & Color & Flavor & Texture & Acceptability \\
\hline \multirow{6}{*}{0} & Thyme & 6.00 & 9.05 & 5.20 & 5.05 & 5.90 \\
\hline & Rosemary & 3.95 & 8.65 & 4.25 & 5.10 & 4.35 \\
\hline & Citrus & 5.85 & 8.15 & 4.90 & 5.04 & 7.15 \\
\hline & Clove & 2.90 & 8.90 & 3.80 & 5.05 & 3.15 \\
\hline & Control 1 & 5.01 & 9.20 & 4.10 & 5.05 & 5.16 \\
\hline & Control 2 & 5.01 & 8.70 & 3.75 & 5.10 & 5.65 \\
\hline \multirow{6}{*}{30} & Thyme & 7.05 & 8.50 & 5.65 & 4.63 & 6.60 \\
\hline & Rosemary & 5.20 & 8.85 & 5.15 & 4.85 & 5.05 \\
\hline & Citrus & 7.10 & 9.20 & 5.90 & 4.80 & 7.05 \\
\hline & Clove & 2.80 & 8.90 & 3.70 & 4.51 & 4.35 \\
\hline & Control 1 & 6.05 & 8.70 & 5.15 & 5.49 & 5.90 \\
\hline & Control 2 & 6.01 & 8.15 & 5.05 & 5.55 & 5.70 \\
\hline \multirow{6}{*}{60} & Thyme & 7.50 & 8.80 & 6.70 & 5.20 & 8.10 \\
\hline & Rosemary & 4.65 & 8.50 & 5.00 & 5.62 & 5.95 \\
\hline & Citrus & 7.85 & 8.90 & 7.65 & 5.50 & 8.25 \\
\hline & Clove & 3.85 & 9.20 & 4.05 & 4.91 & 5.05 \\
\hline & Control 1 & 6.55 & 8.85 & 5.50 & 6.73 & 8.00 \\
\hline & Control 2 & 7.15 & 8.70 & 5.55 & 6.79 & 7.05 \\
\hline \multirow{6}{*}{90} & Thyme & 9.05 & 8.65 & 8.70 & 6.45 & 8.35 \\
\hline & Rosemary & 5.70 & 8.50 & 5.65 & 7.11 & 6.30 \\
\hline & Citrus & 9.20 & 8.80 & 8.25 & 6.90 & 9.00 \\
\hline & Clove & 4.45 & 9.20 & 5.25 & 4.85 & 5.16 \\
\hline & Control 1 & 7.75 & 8.15 & 8.15 & 8.35 & 8.30 \\
\hline & Control 2 & 8.10 & 9.05 & 7.75 & 8.33 & 8.35 \\
\hline
\end{tabular}

Table 2: Results of sensory evaluation of Ras cheese treated with essential oils. Means within the same column followed by the same letters are not significantly different at $\mathrm{P}<0.05$.

hand, eugenol is the major volatile constituent of clove essential oil. Ras cheese flavor was improved in either citrus or thyme essential oil treatment (Table 2). However, both oils replaced ranks during cheese storage. Immediately after treatment, thyme treated cheese was more favoured by the panel than citrus treated cheese. After 30 days or 60 days of storage, citrus was more favoured than thyme treated cheese. Finally, after 90 days of cheese storage thyme treatment was more favoured by the panel. Treatments of clove or rosemary essential oil negatively affected the cheese flavor from the beginning to the end of the storage period. Citrus essential oil is used primarily as aroma and flavoring material in many food products [42-44]. Thyme was also be used to enhance the flavor of several food products. Thyme aromatic herb was used extensively to add a distinctive aroma and flavor to food [45]. Clove, thyme, citrus or rosemary essential oils adversely affected the body and texture of the cheese. Clove oil was the most effective treatment on changing body and texture, followed by thyme, citrus and rosemary, respectively. The effect of the tested essential oils on the texture was increased as the storage period of the cheese increased. The adversely effect of the cheese texture may be due to the anti-proteolytic and lypolytic bacterial effect of the tested essential oils. None of the treated essential oils had an effect on the color of the cheese. Essential oil type affected the general acceptability of the cheese. Ripened cheese treated with citrus or thyme essential oil showed more general acceptability than other treated cheeses.

\section{Conclusion}

Plant essential oils can provide an alternative mean for protecting Ras cheese against mites during ripening, storage and marketing. Clove, citrus, thyme and rosemary essential oils showed acaricidal activity against Ras cheese mite $A$. siro. Degree of acaricidal activity varied according to the type and concentration of the essential oils. Clove oil was found to be the most effective against cheese mites. The tested essential oils can also protect Ras cheese from microorganisms that may be necessary for sustaining growth of mites. Mites may cause significant problems to Ras cheese during ripening, storage and marketing. The predominant Ras cheese mite was identified as A. siro. Mites could be controlled by chemical or physical treatments. However, these treatments may have reverse effects on the cheese properties and consumers' health. There has been increasing interest in the use of natural substances for protecting food staff. Plant essential oils are concentrated hydrophobic liquids containing volatile aroma compounds. Plant essential oils may provide an alternative means for protecting food products [46]. Acceptability is one of the most important criteria for consuming cheese [47]. The organoleptic properties of Ras cheese was found to be affected by the tested essential oils. Ras cheese flavor and odor were found to be improved by citrus or thyme essential oils. Ripened cheese treated with citrus or thyme essential oil showed more general acceptability than other treated cheeses.

\section{References}

1. Hughes AM (1976) The Mites of Stored Food and Houses. University of London and Ministry of Agriculture, Fisheries and Food, London, UK.

2. Renaud J, Gueugnot J, Petavy AF, Guillot J, Coulet M, et al. (1977) Les acariens du fromage: Étude analytique - Préparation d'extraits antigéniques. Revue Française d'Allergologie et d'Immunologie Clinique 17: 247-250.

3. Elziny HM (1981) A study of cheese mites and their effect on the properties of the products.

4. Zdarkova E (1995) Stored product acarology. Modern Acarology 1, Academic Press, Prague. 
Citation: Dawood SAA, Ali FS (2015) Identification and Natural Control of Mite in Ras Cheese. J Food Process Technol 6: 435. doi: $10.4172 / 2157-7110.1000435$

5. Robertson EL (1988) Veterinary pharmacology and therapeutics. lowa state University press, Ames, Indiana.

6. Czernecki N, Kraus H (1978) Mite dermatitis from Tyrophagus dimidiatus. Zeitschrift fur Hautkrankheiten 53: 414-416.

7. Inversen M, Korsgard J, Hallas T, Dahl R (1990) Mite allergy and exposure to storage mites and dust mites in farmes. Clin Exp Allergy 20: 211-219.

8. Sanchez-Ramos I, Castanera P (2009) Chemical and physical methods for the control of the mite Acarus farris on Cabrales cheese. J of Stored Products Research 45: 61-66.

9. Sikorski ZE (2002) Chemical and Functional Properties of Food Components. CRC press. Washington,USA

10. Ozturk M, Govindasamy-Lucey S, Jaeggi JJ, Houck K, Johnson ME, et al (2013) Effect of various high-pressure treatments on the properties of reducedfat Cheddar cheese. Journal of Dairy Science 96: 6792-6806.

11. Bast A (2013) Chemicals and health - Thought for food. Dose-Response 11: 295-300.

12. Duke SO, Cantrell CL, Meepagala KM, Wedge DE, Tabanca N, et al. (2010) Natural toxins for use in pest management. Toxins 2: 1943-1962.

13. Imdorf A, Bogdanov S, Ibanez Ochoa R, Calderone NW (1999) Use of essential oils for the control of Varroa jacobsoni (Oud.) in honey bee colonies. Apidologie 30: $209-228$

14. Pumnuan J, Chandrapatya A, Insung A (2010) Acaricidal Activities of Plant Essential Oils from Three Plants on the Mushroom Mite, Luciaphorus perniciosus Rack (Acari: Pygmephoridae). Pakistan J. Zool. 42: 247-252.

15. Yamamoto $S$ (2008) The roots of natural cosmetics and its modern interpretation. SOFW J. 134: 8-12.

16. Jiang Y, Wu N, Fu YJ, Wang W, Luo M, et al. (2011) Chemical composition and antimicrobial activity of the essential oil of Rosemary. Environ Toxicol Pharmacol 32: 63-8.

17. Turek C, Stintzing FC (2013) Stability of Essential Oils: A Review. Comprehensive Reviews in Food Science and Food Safety 12: 40-53.

18. Hafez SM (1977) Studies on predaceous and parasitic mites of stored product pests. Ain Shams University, Egypt.

19. Gless EE (1972) Life cycle studies of some antarctic mites and description of a new species, Protereunetes paulinae (Acari: Eupodidae). Antractic research Series 20: 289- 306.

20. Webster LM, Thomas RH, McCormack GP (2004) Molecular systematics of Acarus siro L., a complex of stored food pests. Mol Phylogenet Evol 32: 817-22.

21. Frank FJ, Christen LG, Bullerman LB (1992) Standard Methods for the Examination of Dairy Products, American Public Health Association, Washington, USA.

22. Diliello LR (1982) Methods in food and dairy microbiology. Avi. Publishing Company Inc., USA.

23. Melnyk JP, Scott-Dupree C, Marcone MF, Hill A, Smith A, et al. (2010) Identification of cheese mite species inoculated on Mimolette and Milbenkase cheese through cryogenic scanning electron microscopy. Journal of Dairy Science 93: 3461-3468

24. Chmielewski W (2000) Life history parameters of Acarus siro L. (Acari: Acaridae) fed buckwheat. Fagopyrum 17: 73-75.

25. Ranjbar-Bahadori S, Farhadifar N, Mohammadyar L (2014) Assessment of susceptibility of the poultry red mite, Dermanyssus gallinae (Acari: Dermanyssidae) to some plant preparations with focus on exposure time. International Journal of Biological, Veterinary, Agricultural and Food Engineering 8: 530-533.

26. Kamatou GP, Vermaak I, Viljoen AM (2012) Eugenol-From the Remote Maluku Islands to the International Market Place: A Review of a Remarkable and Versatile Molecule. Molecules 17: 6953-6981.

27. George DR, Sparagano OAE, Port G, Okello E, Shiel RS, Guy JH, et al. (2009) Repellence of plant essential oils to Dermanyssus gallinae and toxicity to the non-target invertebrate Tenebrio molitor. Vet. Parasitol 162: 129-134.

28. Marcic D, Peric P, Milenkovic S (2011) Acaricides-biological profiles, effects and uses in modern crop protection. In Pesticides-formulations, effects, (M. Stoytcheva, ed.), InTech, Rijeka, Croatia 37-62.
29. Dayan FE, Cantrell CL, Duke SO (2009) Natural products in crop protection Bioorganic and Medicinal Chemistry 17: 4022-4034.

30. Fuka MM, Wallisch S, Engel M, Welzl G, Havranek J, et al. (2013) Dynamics of Bacterial Communities during the Ripening Process of Different Croatian Cheese Types Derived from Raw Ewe's Milk Cheeses. PLoS ONE 8: e0080734.

31. Fu Y, Zu Y, Chen L, Shi X, Wang Z, et al. (2007) Antimicrobial activity of clove and rosemary essential oils alone and in combination. Phytother Research 21 989-94.

32. Nia Pinto E, Vale-Silva L, Cavaleiro C, Salgueiro L (2009) Antifungal activity of the clove essential oil from Syzygium aromaticum on Candida, Aspergillus and Dermatophyte species. Journal of Medical Microbiology 58: 1454-1462.

33. Cetin B, Cakmakci S, Cakmakci R (2011) The investigation of antimicrobial activity of thyme and oregano essential oils. Turkish Journal of Agriculture \& Forestry 35: 145-154.

34. Fisher K (2008) Potential antimicrobial uses of essential oils in food: is citrus the answer? Trends in Food Science \& Technology 19: 156-164.

35. Bakkali F, Averbeck S, Averbeck D, Idaomar M (2008) Biological effects of essential oils. Rev. Food and Chemical Toxicology 46: 446-475.

36. Burt S (2004) Essential oils: their antibacterial properties and potential applications in foods-a review. International Journal of Food Microbiology 94 223- 253.

37. Dorman HJ, Deans SG (2000) Antimicrobial agents from plants: antibacteria activity of plant volatile oils. Journal of Applied Microbiology 88: 308-316.

38. Kalemba D, Kunick AA (2003) Antibacterial and antifungal properties of essential oils. Curr Med Chem. 10: 813-29.

39. Bassole IH, Juliani HR (2012) Essential oils in combination and their antimicrobial properties. Molecules 17: 3989-4006.

40. Bhuiyan MNI, Begum J, Sardar PK, Rahman MS (2009) Constituents of Peel and Leaf Essential Oils of Citrus Medica L. Journal of Scientific Research 1 : 387-392.

41. Shabnum S, Wagay MG (2011) Essential oil composition of Thymus vulgaris L. and their Uses. Journal of Research \& Development 11: 83-94.

42. Attokaran M (2011) Natural food flavors and colorants. Hoboken, WileyBlackwell, New Jersey.

43. Steuer B, Schulz H, Lager E (2001) Classification and analysis oils by NIR spectroscopy. Food Chemistry 72: 113-117.

44. Nguyen H, Campi EM, Roy Jackson W, Patti AF (2007) Effect of oxidative deterioration on flavour and aroma components of lemon oil. Food Chemistry 112: 388-393.

45. Lee S, Umano K, Shibamoto T, Lee K (2005) Identification of volatile components, in basil (Ocimum basilicum L.) and thyme leaves (Thymus vulgaris L.) and their antioxidant properties. Food Chemistry 91: 131-137.

46. Hernandez-Ochoa L, Aguirre-Prieto YB, Nevarez-Moorillon GV, GutierrezMendez N, Salas-Munoz E, et al. (2014) Use of essential oils and extracts from spices in meat protection. Journal of Food Science and Technology 51 : 957-963.

47. Fresno M, Alvarez S, Diaz E, Virto M, de Renobales M (2014) Sensory profile of raw goat milk cheeses made with artisan kid rennet pastes from commercialweight animals: Alternative to farmhouse goat cheeses. Journal of Dairy Science 97: 6111-6115. 